\title{
BIOLOGY AND CONTROL OF PYPGRASS
}

\author{
K.C. HARRINGTON ${ }^{1}$, L.M. HODDER ${ }^{2}$ and H.A. OUTRED ${ }^{2}$ \\ ${ }^{1}$ Institute of Natural Resources and ${ }^{2}$ Institute of Molecular Biosciences, \\ Massey University, Private Bag 11-222, Palmerston North
}

\begin{abstract}
Pypgrass (Ehrharta villosa) is an invasive rhizomatous grass weed which is smothering the native dune flora at Turakina Beach, near Wanganui. A deep rhizome system, sunken stomata, in-rolled leaves and a mycorrhizal association contribute to the aggressive nature of this weed in the dune community. A field trial showed that haloxyfop will successfully control pypgrass; successive applications give best results. Several other monocotyledons from the dune community were shown in a pot trial to be unaffected by haloxyfop. Studies of pypgrass biology suggest that, although vegetative spread is aggressive, establishment from seedlings is poor. Eradication should be an achievable goal.

Keywords: pypgrass, haloxyfop, mycorrhiza, weed seeds, vegetative spread.
\end{abstract}

\section{INTRODUCTION}

Pypgrass (Ehrharta villosa), a perennial rhizomatous grass species native to South Africa, was introduced to Turakina Beach, $16 \mathrm{~km}$ south of Wanganui, in the early 1960 s to evaluate its ability to stabilise sand dunes. Although pypgrass has never been used in New Zealand for sand stabilisation, there is now a dense infestation of the species in the Kotiata Domain reserve at Turakina Beach and scattered infestations also exist through the nearby Santoft Forest. In parts of the reserve, pypgrass is growing so aggressively that all other species have been excluded. It has long stems which allow the plant to grow up over surrounding vegetation, often to a height of 2 $\mathrm{m}$ or more. As the Department of Conservation is trying to preserve the native dune flora in this reserve (Ravine 1992), eradication is necessary. Turakina Beach appears to be the only place in New Zealand where pypgrass is established at present and, because it appears capable of causing major weed problems, immediate eradication may be prudent.

Microscopic examinations of Turakina Beach specimens of pypgrass by Hodder (1997) have confirmed that plants are the same as those described by Ellis (1987). Pypgrass is a C3 plant, so does not have the physiological advantages of C4 plants with respect to efficient use of water. However, it has sunken stomata over-arched with four cuticular flanges. The leaves are in-rolled, leaving only the adaxial surface, which has very few stomata, exposed to sun and wind. This arrangement of the stomata and leaves would be expected to reduce loss of water from the leaf and thus be of selective advantage in a dry environment.

Field observations on the distribution and spread of pypgrass were made at Turakina Beach. Herbicide experiments were conducted both at Turakina Beach and Massey University. Haloxyfop was chosen for herbicide experiments because a selective, translocated chemical was required to ensure good control of rhizomes while causing minimal damage to non-target native vegetation in the reserve.

\section{Study of vegetative spread}

\section{METHODS AND MATERIALS}

To determine the rate of vegetative spread, six $20 \mathrm{~m}$ long permanent line transects each $4 \mathrm{~m}$ apart were marked out on the edge of the pypgrass infestation in the Kotiata Domain. Each line transect passed from a zone of very dense pypgrass out to an area 
totally devoid of pypgrass. In October 1994 and October 1995, plant species composition and plant density were recorded every $3 \mathrm{~m}$ along each line transect within a $1 \mathrm{~m}^{2}$ quadrat.

\section{Observations of weed biology}

Further information on the biology of pypgrass was obtained from a series of measurements and observations. Seed production was estimated over three separate seasons (1993/94 to 1995/96) by collecting seed-heads from randomly selected $1 \mathrm{~m}^{2}$ quadrats, and counts were made of reproductive tillers, fertile florets per seed-head and the number of viable seeds. Observations were made on the appearance of seedlings at the sites throughout 1994 and 1995. The presence of mycorrhizal associations was investigated both for pypgrass and other nearby plant species using light microscopy and the staining technique described by Phillips and Hayman (1970). Percentage infection was determined by recording presence or absence of mycorrhizal material in a grid, with 600 observations per species (Hodder 1997).

\section{Herbicide field trial}

A field trial was conducted on well-established pypgrass stands in the Santoft Forest. Haloxyfop-ethoxy-ethyl ester (Gallant) was applied to plots (4.3 m by $4.0 \mathrm{~m}$ ) using an LPG-powered precision boom sprayer at $200 \mathrm{kPa}$ and a water rate of 320 litres/ha, with spraying oil (Uptake) added at $10 \mathrm{ml} /$ litre of spray mixture. Six treatments involved application of $1.0 \mathrm{~kg} / \mathrm{ha}$ of haloxyfop, with time of application either in February, April, June, August, October or December 1995, depending on the treatment. Another two treatments involved two split applications of haloxyfop in April and October 1995; one at $0.5 \mathrm{~kg} / \mathrm{h}$ a for each application and the other at $1.0 \mathrm{~kg} /$ ha each time. All treatments were compared against an untreated control, and were replicated five times using a randomised block design, with each block being located at a different site within Santoft Forest. Distance between blocks varied from $0 \mathrm{~m}$ (adjacent blocks) to $1 \mathrm{~km}$.

The effect of each treatment on pypgrass was assessed at 2-monthly intervals after each application by counting the number of new tillers within randomly placed quadrats. Differences between treatments were analysed using the Student-NewmanKeuls multiple range test.

\section{Herbicide pot trial}

Plants of club rush (Isolepis nodosa), flax (Phormium tenax), marram grass (Ammophila arenaria) and pingao (Desmochoenus spiralis) were established in PB 6 planter bags by transplanting field-established specimens. A commercial bark-based potting mixture was used for the flax and pingao, and beach sand fertilised by slowrelease fertiliser (Osmocote) for the other two species. They were kept outdoors at Massey University and watered twice daily by an overhead watering system. Plants were transplanted into the bags then left for 2 months to fully establish before being sprayed on 19 February 1996 . Haloxyfop at 0.5 and $1.0 \mathrm{~kg} / \mathrm{ha}$ was applied using a laboratory pendulum sprayer operating at $200 \mathrm{kPa}$ and delivering 256 litres/ha of spray solution (with oil added as for the herbicide field trial). An untreated control was used for comparison within a completely randomised design with five replicates. Plants were scored for phytotoxicity 2 months after application, with each plant being allocated a score between 0 (dead) and 10 (totally healthy). Results were analysed as for the herbicide field trial.

\section{Study of vegetative spread}

\section{RESULTS AND DISCUSSION}

The position of the outermost pypgrass plant along each line transect had moved between $4.1 \mathrm{~m}$ and $9.0 \mathrm{~m}$ (average of $7.0 \mathrm{~m}$ ) from the main clump of pypgrass over the 12 -month period, which equates to an average rate of lateral spread of $58 \mathrm{~cm}$ per month.

The average tiller density in the dense areas was $109 / \mathrm{m}^{2}$ in October 1994 and $172 / \mathrm{m}^{2}$ in October 1995. Although these densities were low compared with figures for perennial ryegrass exceeding 7000 tillers $/ \mathrm{m}^{2}$ in grazed swards (Matthew 1996), the pypgrass communities were rank un-grazed swards on very drought-prone sand dunes 
with each tiller often exceeding $1 \mathrm{~m}$ in length. The effects of competition were obvious, with less than half the number of plant species present at high pypgrass densities than at lower densities. However Isolepis nodosa, Meulenbeckia complexa, Galium aparine, Sonchus oleraceus, S. asper, Hypochaeris radicata and Lactuca virosa were among the species found growing at all densities of pypgrass. Several of these species are annuals which presumably die as competition for water increases in summer.

\section{Observations on weed biology}

The deep rhizome system of pypgrass should help with competition for water, allowing access to water from deep below the soil surface. A further adaptation of the underground organs which assists with competition on sand dunes is the presence of mycorrhizal associations (Crawley 1993). Measurements showed that pypgrass had a higher level of mycorrhizal infection than most of the other species tested with which it competes at Turakina Beach (Table 1). Only flax had similar levels of infection.

TABLE 1: Percentage mycorrhizal infection found in the roots of some dune plants at Turakina Beach.

\begin{tabular}{llc}
\hline Common Name & Botanical Name & Percentage infection \\
\hline club sedge & Isolepis nodosa & 56.0 \\
flax & Phormium tenax & 70.3 \\
tree lupin & Lupinus arboreus & 7.8 \\
marram grass & Ammophila arenaria & 9.8 \\
pingao & Desmoschoenus spiralis & 42.0 \\
pypgrass & Ehrharta villosa & 88.9 \\
spinifex & Spinifex hirsutus & 57.0 \\
LSD 0.05 & & 22.2 \\
\hline
\end{tabular}

Although pypgrass has effective vegetative reproduction and competes well on sand dunes, it appears less effective at producing seeds and seedlings. At no time during visits to the sites at Turakina Beach were seedlings of pypgrass observed. All new plants were the result of vegetative spread by rhizomes. Many florets produced no seeds, and often there would be less than one viable seed produced per seed head. Seed production was very low at the Kotiata Domain site, varying from 8 to $27 \mathrm{seeds} / \mathrm{m}^{2}$. Production was higher in Santoft Forest, with the highest production measured at 276 seeds $/ \mathrm{m}^{2}$. Highest seed production occurred where pypgrass plants were growing next to tree lupin bushes, suggesting nitrogen may be limiting seed production elsewhere. Poor seed production and the lack of seedlings observed in the field suggests eradication of the species may be possible if existing established plants can be killed. Herbicide field trial

Haloxyfop caused most pypgrass foliage to become necrotic, with this effect occurring most rapidly in spring and autumn, more slowly in summer and slowest in winter (Hodder 1997). Likewise, the $0.5 \mathrm{~kg} / \mathrm{ha}$ rate caused a slower rate of foliar kill than the $1.0 \mathrm{~kg} / \mathrm{ha}$ rate, but a similar level of above-ground damage was eventually caused by both rates.

However, with a rhizomatous perennial weed like pypgrass, control of the underground organs is more important than foliar necrosis. Two months after applying treatments, the number of new tillers emerging from plots was low (Table 2), with no significant differences between any treatments $(\mathrm{P}>0.05)$. Despite this, there were always some new tillers being produced, signifying that a complete kill was never obtained.

Regrowth 4 months after application suggested that applications made in late winter and spring were not as effective as those made in late summer or autumn (Table 2). Best control was obtained when haloxyfop was applied at $1.0 \mathrm{~kg} /$ ha both in autumn and then again in spring to kill off the continued regrowth of recovering rhizomes. 
Note however, that the difference between the lower rate $(0.5 \mathrm{~kg} / \mathrm{ha})$ and the $1.0 \mathrm{~kg} /$ ha rate was not significant.

TABLE 2: Growth of new pypgrass tillers 2 and 4 months after application of $1 \mathrm{~kg} / \mathrm{ha}$ haloxyfop (or $0.5 \mathrm{~kg} / \mathrm{ha}$ in italics) at different times of the year at Turakina Beach.

\begin{tabular}{lccccc}
\hline & \multicolumn{2}{c}{ Conditions when treated } & & \multicolumn{2}{c}{ New tillers $/ \mathrm{m}^{2}$} \\
\cline { 2 - 3 } \cline { 5 - 6 } $\begin{array}{l}\text { Date sprayed } \\
(1995)\end{array}$ & $\begin{array}{c}\text { Air temp. } \\
\left({ }^{\circ} \mathrm{C}\right)\end{array}$ & $\begin{array}{c}\text { Relative } \\
\text { humidity } \\
(\%)\end{array}$ & & $\begin{array}{c}\text { After } \\
2 \mathrm{mths}\end{array}$ & $\begin{array}{c}\text { After } \\
4 \mathrm{mths}\end{array}$ \\
\hline 10 February & 25 & 64 & & 0.5 & $1.7 \mathrm{c} *$ \\
20 April & 24 & 59 & & 0.8 & $1.2 \mathrm{c}$ \\
20 April & 24 & 59 & & 0.6 & $0.7 \mathrm{c}$ \\
10 June & 17 & 68 & & 0.4 & $2.5 \mathrm{bc}$ \\
19 August & 15 & 66 & & 3.2 & $5.0 \mathrm{ab}$ \\
14 October & 19 & 51 & & 0.4 & $7.0 \mathrm{a}$ \\
19 December & 23 & 48 & & 0.5 & - \\
20 Apr/14 Oct & $24 / 19$ & $59 / 51$ & & 3.0 & $2.5 \mathrm{bc}$ \\
20 Apr/14 Oct & $24 / 19$ & $59 / 51$ & & 0.5 & $0.5 \mathrm{c}$ \\
\hline
\end{tabular}

*Means followed by the same letter are not significantly different $(\mathrm{P}>0.05)$.

Results after 4 months could not be used as lateral spread of rhizomes from neighbouring areas was probably occurring. Even the results given in Table 2 need careful interpretation as some of this regrowth may have been occurring from lateral invasion by rhizomes. However, tiller counts were generally taken from the middle of plots to minimise this problem.

Note that a new formulation of haloxyfop (Gallant NF) has been released since this trial was conducted, but this methyl ester of the active isomer of haloxyfop would probably not give different results from those obtained in our work.

\section{Herbicide pot trial}

Of the plants tested for susceptibility to haloxyfop, only marram grass suffered significant levels of damage. No signs of damage were detectable in the pingao or club rush plants (both members of the Cyperaceae family) nor in the flax (Agavaceae family). These results were expected based on information from label recommendations for haloxyfop (O'Connor 1994) and past research results (Harris 1987). Although dicotyledonous plants are generally unaffected by haloxyfop, some uncertainty exists about monocotyledons other than grasses, hence the choice of species tested. Although marram grass was damaged, even $1.0 \mathrm{~kg} / \mathrm{ha}$ did not give complete kill of this species, suggesting that it is reasonably tolerant of haloxyfop. Poor control of marram grass was also noticed in some plots of the field herbicide trial.

\section{CONCLUSION}

Pypgrass is an aggressive competitor under the sandy conditions found at Turakina Beach; its colonisation is assisted by lateral spread from its rhizome system, morphological adaptations to dry conditions, and by mycorrhizal associations. Although pypgrass can be selectively removed from the sites where it is growing at present using haloxyfop, several sequential applications will probably be required, with autumn applications being the most effective. Re-invasion by seedlings once plants have been killed will probably not be a problem.

\section{ACKNOWLEDGEMENTS}

Financial assistance from the New Zealand Plant Protection Society for L.M. Hodder (nee Eustace) and the Massey University Research Fund were much appreciated. 


\section{REFERENCES}

Crawley, M.J., 1993. Succeeding in the sand dunes. Nature 362: 17-18.

Ellis, R.P., 1987. Leaf anatomy of the genus Ehrharta (Poaceae) in southern Africa: the villosa group. Bothalia 17: 195-204.

Harris, B.M., 1987. Haloxyfop: a selective post emergence herbicide for perennial grass weed control. Proc. 40th N.Z. Weed and Pest Control Conf.: 56-58.

Hodder, L.M., 1997. The biology and control of Ehrharta villosa, South African pypgrass. Unpublished masters thesis, Massey University, Palmerston North.

Matthew, C., 1996. Seasonal patterns of root, tiller and leaf production in a Grasslands Ruanui ryegrass. Proc. 58th N.Z. Grassland Assoc.: 73-76.

O’Connor, B., 1994. Novachem Manual - a Guide to Plant Protection in New Zealand, 1994. Novachem Services, Palmerston North.

Phillips, J.M. and Hayman, D.S., 1970. Improved procedures for clearing roots and staining parasitic and vesicular-arbuscular mycorrhizal fungi for rapid assessment of infection. Trans. British Mycological Soc. 55: 158-161.

Ravine, D.A., 1992. Foxton Ecological District - survey report for the protected natural areas programme. Department of Conservation, Wanganui. 